\section{Interaction of Management Factors on Dollar Spot Disease Severity in Tall Fescue Turf}

\author{
A.D. Brede ${ }^{1}$ \\ Department of Horticulture and Landscape Architecture, Oklahoma State \\ University, Stillwater, OK 74078
}

Additional index words. Festuca arundinacea, Lanzia spp., Moellerodiscus spp., Sclerotinia homoeocarpa, cultivar, cutting height, fertilization rate, mowing, nitrogen, seeding rate

\begin{abstract}
A field study was conducted to evaluate the effect of tall fescue (Festuca arundinacea Schreb.) cultivar, seeding rate, $\mathbf{N}$ fertilization rate, and cutting height on the severity of dollar spot (Lanzia and Moellerodiscus spp.) disease incidence. All possible two-factor interactions among these four management factors were statistically significant when averaged over the 2 years of study. Disease severity tended to be lowest at low fescue seeding rate $\left(2100\right.$ pure-live seeds $\left./ \mathrm{m}^{*}\right)$ at the lower $(19 \mathrm{~mm})$ height of cut. 'Mustang', the turf-type cultivar with improved density, was more susceptible to dollar spot than 'Kentucky-31', the common-type cultivar.
\end{abstract}

Dollar spot, incited by Lanzia and Moellerodiscus spp., is a common disease of turfgrasses, affecting numerous turf species including tall fescue (Smiley, 1983). Research reports differ concerning the effect of management factors on dollar spot incidence and severity. In field studies, Cook et al. (1964) and Markland et al. (1969) reported that dollar spot severity in creeping bentgrass (Agrostis palustris Huds.) was inversely related to the level of $\mathrm{N}$ fertilizer applied. Couch and Bloom (1960) reported contrary results

Received for publication 13 Nov. 1990. The cost of publishing this paper was defrayed in part by the payment of page charges. Under postal regulations, this paper therefore must be hereby marked advertisement solely to indicate this fact.

'Current address: Jacklin Seed Co., W. 5300 Riverbend Ave., Post Falls, ID 83854. in a greenhouse study of grasses grown in a sand medium. They found that Kentucky bluegrass (Poa pratensis L.) was less affected by dollar spot under low than under higher $\mathrm{N}$ nutrition.

Little is known about cultivar resistance to dollar spot in tall fescue. To date, no data have been submitted to the national testing program on cultivar resistance in tall fescue (Murray and Morris, 1987).

Dollar spot has been shown to exhibit a positive correlation with seeding rate in Kentucky bluegrass (Brede and Dunfield, 1988). The relationship of seeding rate and dollar spot in tall fescue is unknown.

This study was conducted to examine the interaction of four management factors on the severity of dollar spot in the field: fescue cultivar, seeding and fertilizer rates, and cutting height.
Plots were established 26 Oct. 1984. at the Oklahoma Turfgrass Research Center in Stillwater, on Kirkland silt-loam soil (fine, mixed, thermic, Udertic Paleustoll). Four management factors were tested in a splitplot factorial design. Two cutting heights were evaluated in whole plots, 19- and 57-mm bench-setting height. Two fescue cultivars, Kentucky-31 and Mustang, three seeding rates, $2100,12,900$, and 34,400 pure live seed $/ \mathrm{m}^{2}$ (about equal to 5,29 , and $78 \mathrm{~g}$ seed/ $\mathrm{m}^{2}$, respectively), and two fertilization rates, 4.9 (low) and $24.4 \mathrm{~g} \mathrm{~N} / \mathrm{m}^{2}$ per year (high), were randomized in the subplots. Subplot size was $1.5 \times 2.1 \mathrm{~m}$. Whole and subplot treatments were each replicated three times for a total of nine replicates.

The plot area was fumigated with methyl bromide $\left(\mathrm{CH}_{3} \mathrm{Br}\right)$ at $49 \mathrm{~g} \cdot \mathrm{m}^{-2}$ before planting. Water soluble $10 \mathrm{~N}-0 \mathrm{P}-0 \mathrm{~K}$ starter fertilizer at $9.8 \mathrm{~g} \mathrm{~N} / \mathrm{m}^{2}$ was applied during establishment to the high-N plots. Slow-release sulfur-coated urea $(37 \mathrm{~N}-0 \mathrm{P}-0 \mathrm{~K}, 15 \%$ S), applied in April of each year, made up the balance of the yearly fertilization of the high $\mathrm{N}$ rate and the entirety of the low rate. Soil tests indicated adequate available $\mathrm{P}$ and $\mathrm{K}$ (29 and $112 \mathrm{~g} \cdot \mathrm{m}^{-2}$, respectively). Plots were irrigated during establishment and thereafter as needed to minimize water stress. Grass was clipped twice weekly during the growing season with a Jacobsen walk-behind reel mower (Jacobsen Manufacturing, Racine, Wis.), and clippings were removed.

Dollar spot severity was visually evaluated 1 Aug. 1985 and 16 June 1986, during natural epiphytotics. Inoculum was not required because of uniformity of the natural infection. Plots were visually rated on a scale where $1=$ no visible disease symptoms and $9=$ severe disease with coalescing spots. Ratings were a function of the number of spots per plot. Data were analyzed using a split-plot analysis of variance and the least significant difference procedure at $P \leq 0.05$ 
Table 1. Mean squares and degrees of freedom from split-plot analysis of variance of 1985 and 1986 data of dollar spot severity on tall fescue turf.

\begin{tabular}{lcccc}
\hline & & \multicolumn{3}{c}{ Mean squares (dollar spot severity) } \\
\cline { 2 - 5 } Factor & df & 1985 & 1986 & $1985 / 86$ \\
\hline Replicate & 2 & 6.7 & 2.1 & 3.5 \\
Cutting height (H) & 1 & $174.2^{* *}$ & $63.4^{* *}$ & $11.9^{* *}$ \\
Error a & 2 & 1.6 & 0.5 & 0.9 \\
Fescue cultivar (C) & 1 & $13.5^{* * *}$ & $36.7^{* * *}$ & $23.7^{* * *}$ \\
Fertilization rate (F) & 1 & 0.2 & 4.4 & $1 . .^{* * *}$ \\
Seeding rate (S) & 2 & $66.3^{* * *}$ & $11.2^{* * *}$ & $32.6^{* * *}$ \\
C $\times$ H & 1 & 2.7 & $14.0^{* *}$ & $7.2^{* * *}$ \\
C $\times$ F & 1 & 1.2 & 4.4 & $2.6^{*}$ \\
C $\times$ S & 2 & 1.8 & $4.5^{*}$ & $3.0^{* *}$ \\
F $\times$ H & 1 & 3.6 & $36.7^{* * *}$ & $4.3^{* *}$ \\
F $\times$ S & 2 & $6.6^{* *}$ & 2.8 & $3.8^{* *}$ \\
S $\times$ H & 2 & $9.3^{* * *}$ & 2.7 & $4.5^{* * *}$ \\
H $\times$ C $\times$ S & 2 & 0.3 & 1.9 & 0.9 \\
H $\times$ C $\times$ F & 1 & 0.0 & 0.0 & 0.0 \\
H $\times$ F $\times$ S & 2 & 0.4 & 3.5 & 0.4 \\
C $\times$ F S & 2 & 2.1 & 0.4 & 0.6 \\
H $\times$ C $\times$ F $\times$ S & 2 & 1.5 & 2.6 & 1.8 \\
Error b & 188 & 1.2 & 1.3 & 0.6 \\
\hline
\end{tabular}

Table 2. Interaction of tall fescue cultivar $\times$ seeding rate (pure live seed; PLS) $\times$ fertilization rate $x$ cutting height for dollar spot severity during 2 years of observation.

\begin{tabular}{|c|c|c|c|c|c|c|}
\hline \multirow{4}{*}{$\begin{array}{l}\text { Fescue } \\
\text { cultivar }\end{array}$} & \multirow{4}{*}{$\begin{array}{l}\text { Planting rate } \\
\left(\mathrm{PLS} / \mathrm{m}^{2}\right)\end{array}$} & \multirow{4}{*}{$\begin{array}{l}\text { Fertilization rate } \\
\left(\mathrm{g} \mathrm{N} / \mathrm{m}^{2} \text { per } \mathrm{yr} \text { ) }\right.\end{array}$} & \multicolumn{4}{|c|}{ Cutting ht (mm) } \\
\hline & & & 19 & 57 & 19 & 57 \\
\hline & & & \multicolumn{4}{|c|}{ Year } \\
\hline & & & \multicolumn{2}{|c|}{1985} & \multicolumn{2}{|c|}{1986} \\
\hline & & & \multicolumn{4}{|c|}{ Dollar spot severity } \\
\hline \multirow[t]{5}{*}{ Kentucky-31 } & 2,100 & $\begin{array}{r}4.9 \\
24.4\end{array}$ & $\begin{array}{l}1.0 \mathrm{f}^{\mathrm{z}} \\
1.2 \mathrm{ef}\end{array}$ & $\begin{array}{l}2.1 \mathrm{ef} \\
1.9 \mathrm{f}\end{array}$ & $\begin{array}{l}1.5 \mathrm{~b} \\
1.6 \mathrm{~b}\end{array}$ & $\begin{array}{l}2.8 \mathrm{def} \\
1.8 \mathrm{fg}\end{array}$ \\
\hline & 12,900 & 4.9 & $2.0 \mathrm{bcd}$ & $3.2 \mathrm{cde}$ & $1.8 \mathrm{~b}$ & $2.8 \mathrm{def}$ \\
\hline & & 24.4 & 1.2 ef & $3.8 \mathrm{bcd}$ & $2.3 \mathrm{~b}$ & $1.7 \mathrm{~g}$ \\
\hline & 34,400 & 4.9 & $2.6 \mathrm{ab}$ & $4.2 \mathrm{bc}$ & $1.7 \mathrm{~b}$ & $3.7 \mathrm{bcd}$ \\
\hline & & 24.4 & $1.8 \mathrm{cde}$ & $4.0 \mathrm{bcd}$ & $1.9 \mathrm{~b}$ & $1.6 \mathrm{~g}$ \\
\hline \multirow{6}{*}{ Mustang } & 2,100 & 4.9 & $1.0 \mathrm{f}$ & $1.7 \mathrm{f}$ & $1.7 \mathrm{~b}$ & $2.9 \mathrm{de}$ \\
\hline & & 24.4 & $1.3 \mathrm{def}$ & $2.8 \mathrm{def}$ & $1.7 \mathrm{~b}$ & $2.4 \mathrm{efg}$ \\
\hline & 12,900 & 4.9 & $1.8 \mathrm{cde}$ & $4.0 \mathrm{bcd}$ & $1.3 \mathrm{~b}$ & $4.6 \mathrm{ab}$ \\
\hline & & 24.4 & $2.2 \mathrm{bc}$ & $4.7 \mathrm{ab}$ & $3.6 \mathrm{a}$ & $3.4 \mathrm{cde}$ \\
\hline & 34,400 & 4.9 & $3.2 \mathrm{a}$ & $5.6 \mathrm{a}$ & $2.1 \mathrm{~b}$ & $4.9 \mathrm{a}$ \\
\hline & & 24.4 & $1.9 \mathrm{~b}-\mathrm{e}$ & $4.9 \mathrm{ab}$ & $2.3 \mathrm{~b}$ & $4.0 \mathrm{abc}$ \\
\hline \multicolumn{3}{|c|}{$\mathrm{LSD}_{0.0 s}$ for comparisons between cutting hts } & \multicolumn{2}{|c|}{2.03} & \multicolumn{2}{|c|}{1.86} \\
\hline
\end{tabular}

${ }^{2}$ Mean separation within columns by LSD test, $P \leq 0.05$. Plots were rated on a scale where $1=$ no visible disease and $9=$ severe disease. Ratings were a function of the number of spots per plot.

as described by Milliken and Johnson (1984).

The main effects of cutting height, cultivar, and seeding rate were highly significant each year (Table 1). The fertilization rate main effect was nonsignificant; however, fertilization rate had a significant interaction with seeding rate in 1985 and cutting height in 1986. The previous fertility of the soil and the range of fertilizer rates chosen may have contributed to the lack of significance of the fertilizer main effect.
In general, dollar spot was more severe at the higher height of cut. Diseases caused by fungi that colonize cut leaf tips, such as Lunzia spp., often can be minimized by factors that promote faster removal of leaf tips (Smiley, 1983). Closer mowing, presumably, would remove leaf tips more frequently than higher mowing. Most turfgrass diseases, however, decrease in severity with increasing cutting height (Smiley, 1983).

The profound effect of seeding rate on dis- ease severity continued 2 years after establishment (Table 1). The effects were most pronounced at the higher cutting height (Table 2). High seeding rates produce turf stands with high plant densities. Plants at higher densities tend to be smaller and may have reduced ability to resist or recover from disease than the larger plants associated with low plant density. Brede and Duich (1982) detected significant effects of seeding rate on Kentucky bluegrass shoot density 42.5 months after sowing. Therefore, the effects of seeding rate on disease incidence appear not to be transitory but may persist for several years after establishment.

'Mustang', the improved turf-type cultivar, generally was more susceptible to dollar spot than 'Kentucky-31', the common-type cultivar (Table 2). Perhaps the greater disease severity in 'Mustang' can be traced to its high shoot density.

This study has shown that fescue cultivar, seeding rate, and cutting height may influence the development of dollar spot disease in the turfgrass environment. Further, $\mathrm{N}$ fertilization rate may interact with the latter two factors.

\section{Literature Cited}

Brede, A.D. and J.M. Duich. 1982. Cultivar and seeding rate effects on several physical characteristics of Kentucky bluegrass turf. Agron. J. $74: 865-870$

Brede, A.D. and T.J. Dunfield. 1988. Seeding rate: Its effect on disease and weed encroachment. Proc. 42nd Northwestern Turfgrass Conf. 42:90-97.

Cook, R.N., R.E. Engel, and S. Bachelder. 1964. A study of the effect of nitrogen carriers on turfgrass disease. Plant Dis. Rptr. 48:254-255.

Couch, H.B. and J.R. Bloom. 1960. Influence of environment on diseases of turfgrasses. II. Effect of nutrition, $\mathrm{pH}$, and soil moisture on Sclerotinia dollar spot. Phytopathology 50:761-763.

Markland, F.E., E.C. Roberts, and L.R. Fredeick. 1969. Influence of nitrogen fertilizers on Washington creeping bentgrass, Agrostis palustris Huds. II. Incidence of dollar spot, Sclerotinia homoeocarpa, infection. Agron. J. 61:701-705.

Milliken, G.A. and D.E. Johnson. 1984. Analysis of messy data. vol. I: Designed experiments. Lifetime Learning Pub., Belmont, Calif.

Murray, J.J. and K.N. Morris. 1987. National tall fescue test-1983, final report 1984-87. U.S. Dept. Agr. PSI no. 8, Beltsville, Md.

Smiley, R.W. 1983. Compendium of turfgrass diseases. Amer. Phytopathol. Soc., St. Paul, Minn. 